
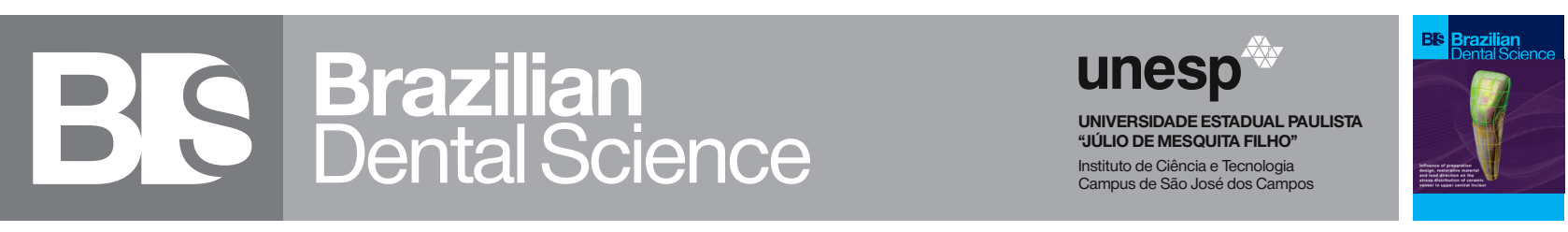

\title{
Mechanical and thermal stress analysis of hybrid ceramic and lithium disilicate based ceramic CAD-CAM inlays using 3-D finite element analysis
}

Análise do estresse mecânico e térmico de inlays de cerâmica hibrida e de cerâmica a base de dissilicato de lítio através da análise em 3D de elementos finitos

Sameh Mahmoud NABIH ${ }^{1}$, Nady Ibrahim Mohamed HASSANIN ${ }^{2}$, Ahmed Ramadan ELMANAKHLY ${ }^{3}$

1 - Operative dentistry and Vice dean for post graduate students, Faculty of Dental Medicine, Al-Azhar University (boys-Cairo).

2 - Operative Dentistry Department, Faculty of Oral and Dental Medicine, Al-Azhar University.

3 - Operative Dentistry Department, Faculty of Oral and Dental Medicine, Al-Azhar University (boys-Cairo).

\section{ABSTRACT}

Objective: The aim of this study was to analyze mechanical and thermal stresses of hybrid ceramic and lithium disilicate based ceramic of CAD/CAM inlays using 3D Finite element analysis. Material and Methods: A three dimensions finite element model of permanent maxillary premolar designed according to standard anatomy with class II cavity preparation for inlay restored with two different ceramic materials: 1- Hybrid ceramic (Vita Enamic), 2- Lithium disilicate based ceramic (IPS e.max CAD). Totally six runs were performed on the model as: One loading case for each restorative material was tested in stress analysis; seven points of loading with $140 \mathrm{~N}$ vertically applied at palatal cusp tip and cusp slop, marginal ridges and central fossa while the models base was fixed as a boundary condition in the two cases. Two thermal analysis cases were performed for each restoration material by applying $5^{\circ} \mathrm{C}$ and $55^{\circ} \mathrm{C}$ on the crown surface including the restoration surface. Results: The results of all structures were separated from the rest of the model to analyze the magnitude of stress in each component. For each group, maximum stresses on restorative materials, cement, enamel, and dentin were evaluated separately. Both ceramic materials generated similar stress

\section{RESUMO}

Objetivo: O objetivo deste estudo foi analisar o estresse mecânico e térmico de inlays de cerâmica hibrida e a base de dissilicato de lítio através da análise em 3D de elementos finitos. Material e Métodos: Foi realizado o design de um modelo de três dimensões em elementos finitos de um pré-molar superior de acordo com os padrões anatômicos de um preparo de cavidade classe II para restauração de inlay em dois tipos de cerâmicas diferentes: 1 Cerâmica hibrida (Vita Enamic), 2 - Cerâmica a base de dissilicato de lítio (IPS e.max CAD). No total, seis execuções foram realizadas no modelo como: Uma carga para cada material restaurador foi testado para análise de tensão; sete pontos de carga com $140 \mathrm{~N}$ foi aplicado verticalmente na ponta da cúspide palatina, saliência da cúspide, cristas marginais e fossa central enquanto a base do modelo foi fixada como uma condição de limite nos dois casos. Duas análises térmicas foram realizadas para cada material de restauração, aplicando $5^{\circ} \mathrm{C}$ e $55^{\circ} \mathrm{C}$ na superfície da coroa, incluindo a superfície da restauração. Resultados: Os resultados de todas as estruturas foram separados do resto do modelo para analisar a magnitude do estresse de cada componente. Para cada grupo, o máximo de estresse nos materiais restauradores, cemento, esmalte e dentina foram avaliados separadamente. Padrões similares de distribuição de estresse foram gerados em todos os grupos para ambos os materiais cerâmicos, quando a carga oclusal de $140 \mathrm{~N}$ foi 
distribution patterns for all groups when a total occlusal load of $140 \mathrm{~N}$ was applied. Conclusion: Thermal fluctuations of temperature have a great influence on the stresses induced on both restoration and tooth structure. IPS e.max CAD produced more favorable stresses on the tooth structure than Vita Enamic.

\section{KEYWORDS}

Ceramics; Finite element analysis; IPS e.max CAD; Lithium disilicate; Vita Enamic. aplicada. Conclusão: As variações térmicas de temperatura têm uma grande influência nas tensões induzidas na restauração e na estrutura dentária. IPS e.max CAD produziu tensões mais favoráveis na estrutura dentária do que o Vita Enamic.

\section{PALAVRAS-CHAVE}

Análise de elementos finitos; Dissilicato de lítio; Cerâmica; IPS e.max CAD; Vita Enamic.

\section{INTRODUCTION}

$\mathrm{P}$ reclinical in vitro testing of dental materials is crucial to prove their mechanical capability and compatibility to service in the oral cavity. The oral environment surrounding dental restorations incorporates many challenging conditions like humidity, acidic or basic $\mathrm{pH}$, and cyclic loading [1]. Accordingly, laboratory testing should simulate different aspects of the oral environment to produce failure modes like those seen clinically [2]. Clinically, mechanical failure of dental restorations occurs after many years in service, indicating a fatigue failure rather than acute overload [3].

Recently, finite element analysis (FEA) has been used in biomechanical researches of clinical situations and various areas of dentistry [4]. In fact, some dental and medical studies have been conducted on living subjects. They are costly and ethically skeptical. Using virtual models and simulations can help improve research results and reduce the cost of in vitro and in vivo experiments [5]. Up to date, inconsistent and conflicting results have been reported from studies investigating the effect of inlay or onlay cavity design and restorative materials on stress distribution in the tooth-restoration complex [6]. Therefore, it was speculated that it would be of importance to analyze the stresses of hybrid ceramic and lithium disilicate based ceramic CAD/CAM inlays.
The finite element analysis is a method in which geometry of the subject to be analyzed is described through a certain number of geometrical entities (elements) connected in nodes. The stress and strain distribution are derived from displacements calculated in each node. This method permits the response evaluation of a natural system under various loads and conditions [7]. The human teeth cannot be represented through the two finite element analysis dimensional model. Therefore, the actual and structural response cannot be simulated without considering the third dimension.

Finite element analysis results allow a better knowledge in comprehending the actual process which conducts to failure, while in vitro studies reveal the maximum load to failure for the system being tested [8]. The aim of this study was to analyze mechanical and thermal stresses of hybrid ceramic and lithium disilicate based ceramic CAD-CAM inlays using 3D finite element analysis.

\section{MATERIAL AND METHODS}

\section{Materials}

Two types of ceramic blocks and one type of adhesive system were utilized in this study.

\section{A-Ceramic blocks}

1. IPS e.max CAD HT A2 B 40L, Lithium disilicate ceramic. 
2. Vita Enamic 2M2 HT EM-14, Hybrid ceramic (Polymer infiltrated ceramic network).

\section{B-Cement system}

Rely X Unicem, Dual cure self-adhesive universal resin cement.

All materials used in the present study, composition, manufacture, batch number and website are listed in Table I.

Table I - Materials used in the study

\begin{tabular}{|c|c|c|c|}
\hline Material & Category & Composition & $\begin{array}{l}\text { Manufacture } \\
\text { Batch no. } \\
\text { Website }\end{array}$ \\
\hline $\begin{array}{l}\text { IPSe.max } \\
\text { CAD }\end{array}$ & $\begin{array}{l}\text { Lithium } \\
\text { Disilicate }\end{array}$ & 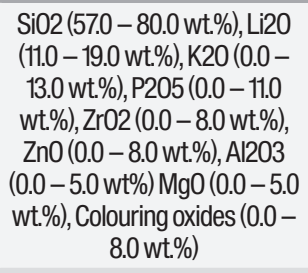 & $\begin{array}{c}\text { Ivoclar vivadent. } \\
\text { Liechtenstein } \\
\text { (17284) } \\
\text { www.ivoclarvivadent. } \\
\text { com/ }\end{array}$ \\
\hline $\begin{array}{l}\text { VITAENA- } \\
\text { MIC }\end{array}$ & $\begin{array}{l}\text { Hybird } \\
\text { ceramic }\end{array}$ & $\begin{array}{c}\text { Ceramic part: SiO2 (58.0- } \\
63.0 \text { wt.\%), Al203 (20.0 - } 23.0 \\
\text { wt.\%), NaO2 (9.0 - } 11.0 \text { wt.\%), } \\
\text { K02 (4.0 - 6.0 wt.\%), B203 } \\
\text { (0.5 - 2.0 wt.\%), ZrO2 (> 1.0 } \\
\text { wt.\%), Ca0 (> 1.0 wt.\%) } \\
\text { polymer part: UDMA (uretha- } \\
\text { ne dimethacrylate), TEGDMA } \\
\text { (triethylene glycol dimetha- } \\
\text { crylate) }\end{array}$ & $\begin{array}{c}\text { VITA Zahnfabrik. } \\
\text { Germany } \\
\text { (56761) } \\
\text { www.vita-zahnfabrik. } \\
\text { com/ }\end{array}$ \\
\hline $\begin{array}{c}\text { RelyX } \\
\text { Unicem }\end{array}$ & $\begin{array}{l}\text { Self-adhesive } \\
\text { universal } \\
\text { resin cement }\end{array}$ & $\begin{array}{l}\text { Powder: Alkaline(basic)fillers, } \\
\text { Silanated fillers, Intitiator } \\
\text { components, Pigments } \\
\text { Liquid: Methacrylate mono- } \\
\text { mers containing phosphoric } \\
\text { acid group, initiator compo- } \\
\text { nents, stabilizers }\end{array}$ & $\begin{array}{c}\text { 3M ESPEDental } \\
\text { Products St.Paul, } \\
\text { MN,USA } \\
\text { (3765311) } \\
\text { www.3m.com/ }\end{array}$ \\
\hline
\end{tabular}

\section{METHODS}

\section{analysis}

Three-Dimensional finite element

The simulated clinical design was class II cavity preparation of upper second premolar for inlay with two different materials:

- Lithium disilicate material (IPS e.max CAD)

- Hybrid ceramic (Vita Enamic)

The generalized steps to perform a finite element analysis can be summarized as follows:
1. Construction of geometrical model to build solid volumes.

2. Finite element modeling and selection of element type to suit the case study.

3. Definition of the materials properties.

4. Mesh generation (nodes and elements generation).

5. Application of load, and boundary conditions.

6. Obtaining the data of resultant stresses and comparing the results.

\section{Planned design details were as follows}

Class II cavity preparation on the second premolar with pulpal floor depth $2.5 \mathrm{~mm}$ and $1.5 \mathrm{~mm}$ axial wall creating a class II box which is $4 \mathrm{~mm}$ occlusogingivally and gingival floor of $2 \mathrm{~mm}$.

\section{Model scanning}

A Three dimensional (3D) finite element model was constructed by 3D scanning of a sample tooth (second premolar). The tooth geometry was acquired by using laser scanner (Geomagic Capture, 3D Systems, Cary, NC, USA). Such scanner produced data file containing a cloud of points coordinates. An intermediate, software was required (Rhino 3.0 - McNeel inc., Seattle, WA, USA) to trim a newly created surface by the acquired points. Then, the solid (closed) tooth geometry was exported to finite element program as STEP file format.

\section{Geometric model preparation}

First, the directions were set up (top, bottom, mesial, distal, anterior, posterior) followed by the mask thresholds to define the mask of enamel and the mask of dentin and to define tooth tissues with its mechanical properties lately and finally, we calculate 3D object.

We used "cut orthogonal to screen" tool to cut through the tooth to reproduce the inlay of the premolar, then we formed the pulpal extension part by cutting in the facial aspect and proximal surface of the premolar, then the 
two parts were merged to form the whole inlay (Figure 1).

Then all the dentin parts were merged followed by enamel part construction to be applied in the finite element analysis test with its mechanical properties.
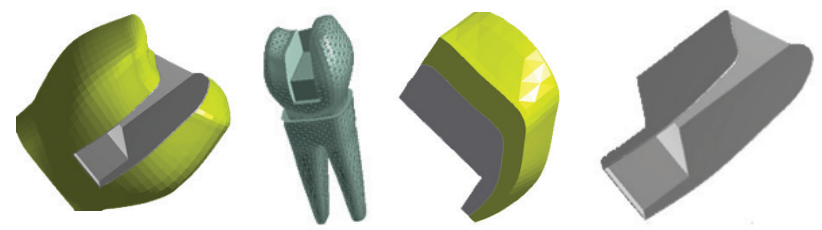

Figure 1- Geometric construction of; (a) Enamel, (b) Dentin, (c) Restoration and (d) Cement.

A cement layer of $60 \mu \mathrm{m}$ was created by using a set of vertical and horizontal planes and applying set of Boolean operations (divide, cut, add, etc.) to keep the cement layer separated from the tooth and the restoration. All these parts were exported in the form of STL files then imported into the software (3-matic 7.01 (Materialise NV).

\section{Meshing}

All materials used in this study assumed to be homogenous, isotropic and to possess linear elasticity. Each of the model components (bone, cement and restoration) was assigned to a material property on the finite element package ANSYS Workbench version 16 (ANSYS Inc., Canonsburg, PA, US). Materials properties used in this study are presented in Table II. The parabolic tetrahedral element was used for meshing the model, that adequate mesh density was selected to ensure results accuracy for the discrete model. Mesh density of all model components is presented in Table 3. The model components on ANSYS screen after meshing was illustrated (Figure 2).
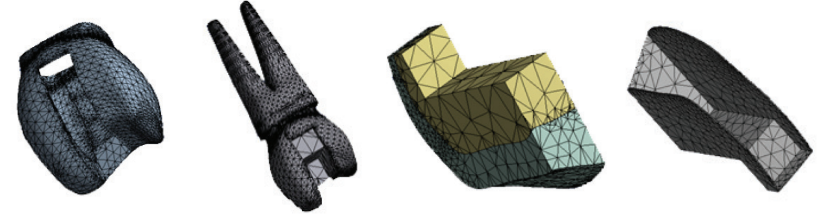

Figure 2 - Meshed model components; (a) Dentine, (b) Enamel, (c) Cement, (d) Restoration.
Table II - Materials properties used in the finite element analysis

\begin{tabular}{cccccc} 
Material $\begin{array}{c}\text { Young's } \\
\text { modulus } \\
(\mathrm{GPa})\end{array}$ & $\begin{array}{c}\text { Poisson } \\
\text { ratio }\end{array}$ & $\begin{array}{c}\text { Coefficient } \\
\text { of thermal } \\
\text { expansion }\end{array}$ & $\begin{array}{c}\text { Thermal } \\
\text { conductivity } \\
\left(\mathrm{W} / \mathrm{mm}^{\circ} \mathrm{C}\right)\end{array}$ & $\begin{array}{c}\text { Specific } \\
\text { heat } \\
\left(\mathrm{J} / \mathrm{kg}^{\circ} \mathrm{C}\right)\end{array}$ \\
$\begin{array}{c}\text { Enamel } \\
84\end{array}$ & 0.33 & $17 \times 10^{-6} /{ }^{\circ} \mathrm{C}$ & $9.2 \times 10^{-3}$ & 750 \\
$\begin{array}{c}\text { Dentin } \\
\text { Spongy } \\
\text { bone }\end{array}$ & 18.6 & 0.31 & $10.6 \times 10^{-6} /{ }^{\circ} \mathrm{C}$ & $6.3 \times 10^{-3}$ & 1170 \\
$\begin{array}{c}\text { Cortical } \\
\text { bone }\end{array}$ & 13.7 & 0.30 & $10 \times 10^{-6} /{ }^{\circ} \mathrm{C}$ & $5.8 \times 10^{-3}$ & 1840 \\
$\begin{array}{c}\text { Relay-X } \\
\text { IPS }\end{array}$ & 7.7 & 0.30 & $39 \times 10^{-6} /{ }^{\circ} \mathrm{C}$ & $2.61 \times 10^{-3}$ & 1150 \\
$\begin{array}{c}\text { e-max } \\
\text { CAD }\end{array}$ & $95 \pm 5$ & 0.23 & $10.6 \times 10^{-6} /{ }^{\circ} \mathrm{C}$ & $2.5 \times 10^{-3}$ & 975.5 \\
$\begin{array}{c}\text { Vita } \\
\text { Enamic }\end{array}$ & 30 & 0.23 & $15.5 \times 10^{-6} /{ }^{\circ} \mathrm{C}$ & $8.7 \times 10^{-3}$ & 820 \\
\hline
\end{tabular}

Table III - Mesh density

\begin{tabular}{|c|c|c|}
\hline Component & No of nodes & No of elements \\
\hline Cortical bone & 17,429 & 8,978 \\
\hline Spongy bone & 36,618 & 21,939 \\
\hline Dentine & 68,416 & 39,886 \\
\hline Enamel & 76,605 & 44,055 \\
\hline Cement & 7,717 & 3,564 \\
\hline Restoration & 12,131 & 6,423 \\
\hline
\end{tabular}

Totally six runs were performed on the model as: One loading case for each restoration material was tested in stress analysis; seven points of loading with $140 \mathrm{~N}$ vertically applied at palatal cusp tip and cusp slop, marginal ridges and central fossa while the models base was fixed as a boundary condition in the two cases. Two thermal analysis cases were performed for each restoration material by applying $5^{\circ} \mathrm{C}$ and $55^{\circ} \mathrm{C}$ on the crown surface including the restoration surface, while maintaining bone at $37^{\circ} \mathrm{C}$. The solid modeling and finite element analysis (linear static and thermal analysis) were performed on Laptop (Dell Inspiron 5000, with Core I7, 2.4 GHz processors, 6G). 


\section{RESULTS}

The results of all structures were separated from the rest of the model to analyze the distribution and magnitude of stress in each component. For each group, maximum stresses on restorative materials, cement, enamel, and dentin were evaluated separately. Both ceramic materials generated similar stress distribution patterns for all groups when a total occlusal load of $140 \mathrm{~N}$ was applied onto functional cusp, marginal ridges, and central fossa.

\section{1) Mechanical loading}

\section{1) Mechanical loading for Vita Enamic group}

Von Mises stresses of restoration, cement, enamel and dentin of order 305.23 MPa, 25.288 $\mathrm{MPa}, 859.99 \mathrm{MPa}$ and $130.260 \mathrm{MPa}$ respectively (Figure 3).

\section{2) Mechanical loading for IPS e.max} CAD group

Von Mises stresses of restoration, cement, enamel and dentin of order $303.12 \mathrm{MPa}, 33.63$ $\mathrm{MPa}, 859.98 \mathrm{MPa}$ and $121.61 \mathrm{MPa}$ respectively (Figure 4).

\section{2) Thermal loading:}

2.1) Thermal loading at $5^{\circ} \mathrm{C}$ for Vita Enamic group

Von Mises stresses of restoration, cement, enamel and dentin of order $35.339 \mathrm{MPa}, 14.106$ $\mathrm{MPa}, 65.974 \mathrm{MPa}$ and 27.4480 MPa respectively (Figure 5).

\section{2) Thermal loading at $5^{\circ} \mathrm{C}$ for IPS e.max CAD group}

Von Mises stresses of restoration, cement, enamel and dentin of order 22.462MPa, 9.1694 $\mathrm{MPa}, 58.694 \mathrm{MPa}$ and 27.877 MPa respectively (Figure 6).

\section{3) Thermal loading at $55^{\circ} \mathrm{C}$ for Vita Enamic group}

Von Mises stresses of restoration, cement, enamel and dentin of order $64.2650 \mathrm{MPa}$, 29.0320 MPa, 124.04 $\mathrm{MPa}$ and $33.498 \mathrm{MPa}$ respectively (Figure 7).

\section{5) Thermal loading at 55o $\mathrm{C}$ for IPS e.max group}

Von Mises stress of restoration, cement, enamel and dentin of order $50.648 \mathrm{MPa}, 24.389$ $\mathrm{MPa}, 95.463 \mathrm{MPa}$ and $51.86 \mathrm{MPa}$ respectively (Figure 8).

Results analysis for mechanical and Thermal loadings at on Vita Enamic and IPS e.max CAD restorations (Figure 9-12).
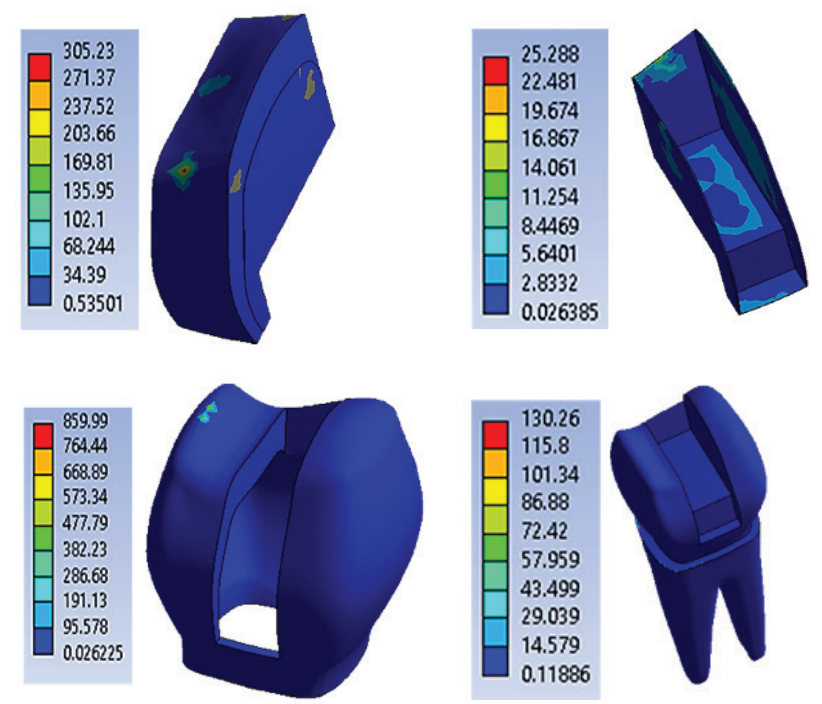

Figure 3 - Von Mises Stress (equivalent stress) of Vita Enamic after mechanical loading; (a) Restoration, (b) Cement, (c) Enamel and (d) Dentin.

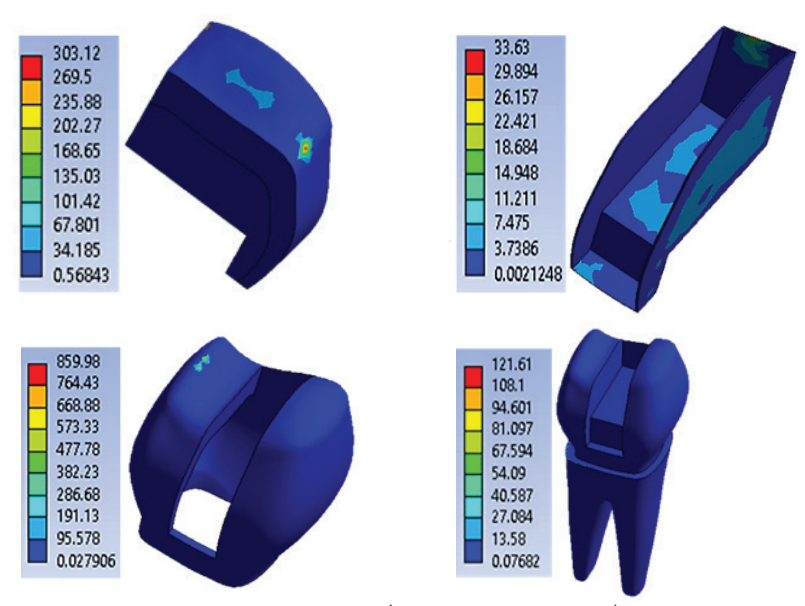

Figure 4 - Von Mises Stress (equivalent stress) of IPS e.max CAD after mechanical loading; (a) Restoration, (b) Cement, (c) Enamel and (d) Dentin. 



Figure 5 - Von Mises Stress (equivalent stress) of Vita Enamic after thermal loading at 5 degree; (a) Restoration, (b) Cement, (c) Enamel and (d) Dentin.
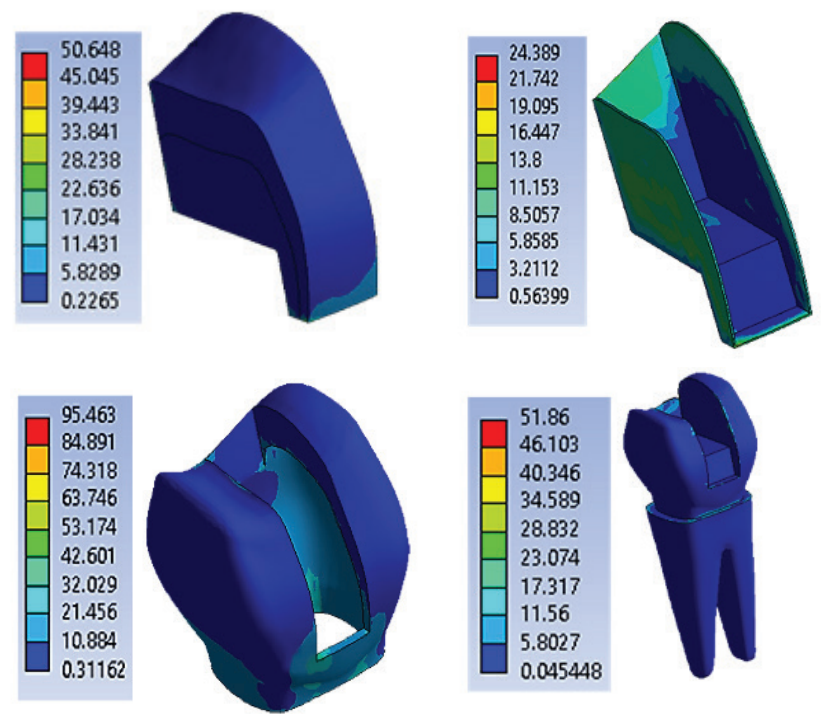

Figure 6 - Von Mises Stress (equivalent stress) of IPS e.max CAD after thermal loading at 5 degree; (a) Restoration, (b) Cement, (d) Enamel and (e) Dentin.
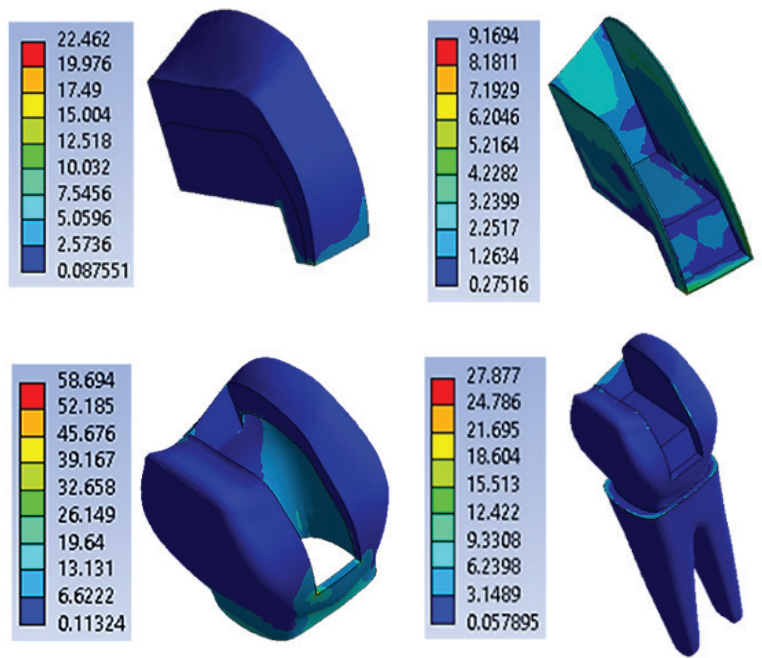

Figure 7 - Von Mises Stress (Equivalent stress) of Vita Enamic after thermal loading at 55 degree; (a) Restoration, (b) Cement, (c) Enamel and (d) Dentin.
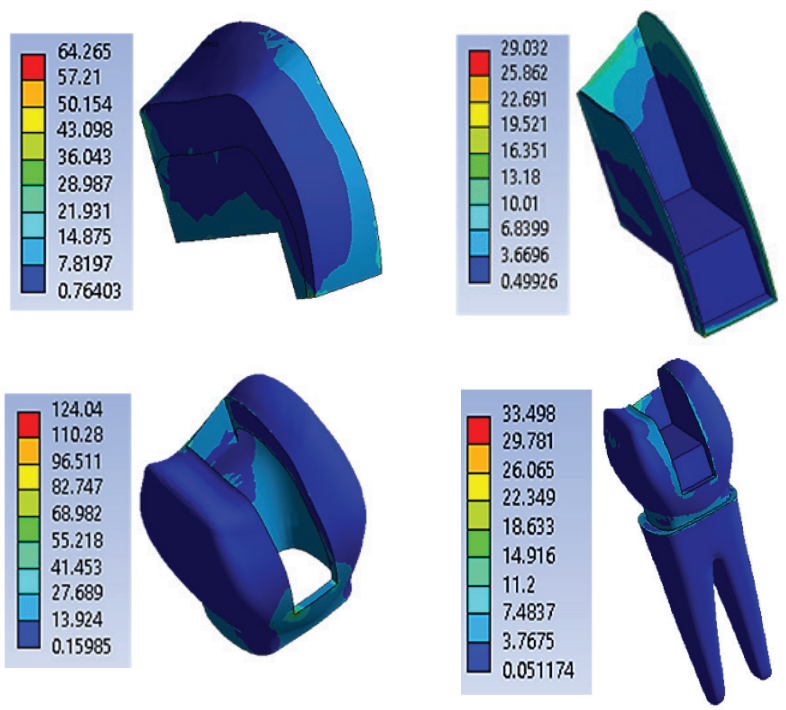

Figure 8 - Von Mises Stress (Equivalent stress) of IPS e.max CAD after thermal loading at 55 degree; (a) Restoration, (b) Cement, (d) Enamel and (e) Dentin. 




Figure 9 - Column chart showing von mises stresses after mechanical loading.

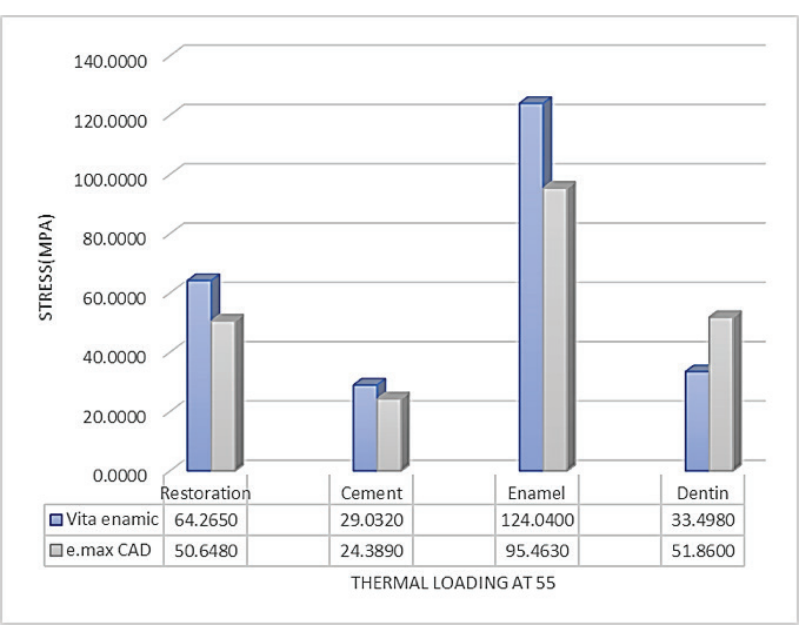

Figure 10 - Column chart showing von mises stresses after thermal loading at 5 degree.



Figure 11 - Column chart showing von mises stresses after thermal loading at 55 degree.

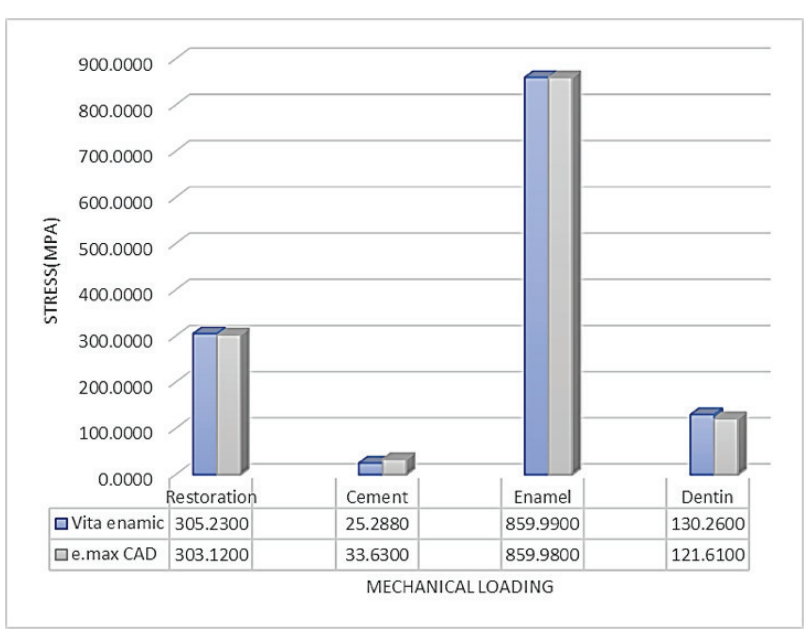

Figure 12 - Column chart showing total von mises stresses of Vita Enamic and IPS e.max CAD restorations.

\section{DISCUSSION}

Ceramic materials are sensitive to tensile forces and their mechanical resistance is highly influenced by the presence of superficial scratches and internal voids. Such defects may serve as sites of initiation of cracks. This phenomenon is also influenced by factors such as marginal design, thickness of restoration, residual pressure, porosity, intensity, direction and frequency of applied loads, modulus of elasticity of restoration components, interfacial defects between the restoration and cement and oral conditions [9].

Hot and cold liquid drinks in the mouth cause a temperature gradient that results in thermal stresses because of the different physical and thermal properties of different materials in the restored tooth. The thermal stresses which occur in the restored tooth are dependent on many factors such as the properties of restorative materials, preparation design and adhesive resistance between tooth and restorative materials [10].

Considering the above explained parameters, the thermal loads were determined as $5^{\circ} \mathrm{C}$ (for cold liquids) and $55^{\circ} \mathrm{C}$ (for hot liquids). In heat variations, the heat on the outer surface of the material can be lower or higher than the temperature of the environment. The reason for this is the transition of heat by convection to the outer surface. The heat transfer among the materials occurs via conduction. Thus, increase 
or decrease in temperature results in thermal stresses.

The thermal stresses could result in tension stresses that facilitate the initiation of cracks and/ or subcritical crack growth within the ceramic specimens, thereby enabling catastrophic failure. In addition, the thermal stresses could cause interfacial degradation and debonding due to differences in coefficient of thermal expansion and contraction of the tooth, cement and restoration [11].

Values from Finite Element Analysis are divided as von mises stress, maximum principle stress (tensile stress), minimum principle stress (compressive stress) and shear stress. However, in the majority of finite element studies presented in the literature, von mises stress is used as analysis criteria and there is also evidence that the selection of the von mises criteria seems to be reliable because brittle materials, which the tooth is a member of, fail primarily because of tensile and compressive types of stress [12]. Therefore, it was decided to use the von mises stress, once it is the type of stress most used and referred in the literature. In the present study, qualitative analysis of stress distribution was performed using von mises stress diagrams. Von mises stress is essentially an aggregated stress which combines tensile, compressive and shear stresses [13].

The $140 \mathrm{~N}$ loads used in this study were chosen, as average chewing force, which is supposed to be the one third of the maximum biting force [14].

The elastic modulus of the material that will support the ceramic restoration should be assessed when considering the use of base materials or selecting a material for a buildup. Materials with lower elastic modulus may lead to decreased strength of the restoration [15].

A finite element analysis was arranged to thermal stress distribution in a restored tooth. The factors which may account for the differences in stress levels include crown geometry, boundary conditions, type, size and number of elements and loading condition. To analyze the stress distribution in our finite element analysis, the influence of the pulp chamber on the stress distribution was ignored, all materials were assumed to be linearly elastic and isotropic and they remained elastic under applied thermal loads. The cement was assumed to bond perfectly to ceramic and dentine [16].

The results of this study revealed that the total von mises, shear stresses, tensile stresses, compressive stresses and total deformation of Vita Enamic is higher than that of IPS e.max CAD in enamel, dentin and cement at the cervical area, occlusal enamel and marginal ridge. This agreed with Gulec and Ulusoy in 2017 [17] who found that the highest von mises stress values were observed in Vita Enamic, while the lowest stress value was observed in feldspathic ceramic. These findings are consistent with the results of the study which defended that materials with low elastic moduli transferred more stress to dental tissues [18].

Also, our results agreed with Yin et al. in 2019 [19]. They stated that these results may be related to the fact that polymer infiltrated ceramic network has low fracture resistance and flexural strength than Glass ceramics which case more stresses on the restoration and surrounding structure at the applied magnitude of load. The results of our study also showed that tensile stresses were smaller than the compressive stresses which was also in agreement with Lin et al. in 2001 [20], Ausiello et al. in 2002 [21], Rees et al. in 2003 [22], Federlin et al. in 2007 [23] and Ausiello et al. in 2011 [5]. These results may be attributed to the combination of axial and bending stresses in compression. The compressive stresses were considerably higher at the palatal cervical area and smaller at the buccal cervical area, this might be the result of tooth bending caused by a perpendicular component of loadings to the longitudinal axis.

The results contradicted with those of Dejak and Mlotkowski in 2008 [24] who reported that the restorative material influences adhesive and cohesive failures in adhesive resin. In their study, the stress values in the composite resin model were lower than the ceramic models. This result may be attributed to the similar elastic moduli of composite resin used compered to both the dentin 
and adhesive resin. Despite the relatively higher thermal expansion, composite resin absorbs loads without conducting stresses to adhesive resin.

The influence of simultaneous thermomechanical loads on stress distribution associated with two types of inlays was investigated by finite element analysis. The different properties of the restorative materials did not affect the stress distribution. However, the stresses resulting from combined thermomechanical loads were considerably higher than those caused by mechanical loading alone [25].

Temperature changes also create thermal stress on restored teeth. This study demonstrated that tensile stresses and total deformation created by cold exposure was greater than that with hot exposure. This result agreed to the studies of Oskui et al. in 2014 [26] and Gungor et al. in 2010 [27]. These findings may be related to the daily and natural temperature difference between drinkable materials and the oral environment. The temperature difference between $37^{\circ} \mathrm{C}$ and $5^{\circ} \mathrm{C}$ was significantly higher than $37^{\circ} \mathrm{C}$ to $55^{\circ} \mathrm{C}$.

The stress distribution within the tooth was reversed by the type of thermal exposure. Cold conditions caused tensile stress on the enamel and restoration surface, and compressive one in the dentin, whereas hot conditions caused compressive stress on the enamel and restoration surface, and tensile one in the dentin. These results are consistent with Toparli and Sasaki in 2003 [28], Cornacchia et al. in 2010 [29], Pałka et al. in 2012 [30] and Oskui et al. in 2014 [26].

Polymer infiltrated ceramic network had the highest thermal expansion coefficient and exhibited higher stress values compared with lithium disilicate ceramic because of the change in volume. A mismatch between the thermal expansion coefficients of the restorative materials and the tooth will result in differential expansion and contraction during intraoral temperature changes. Several studies have reported that thermal stress concentrations occur at biomaterial interfaces [31].

This study had some limitations such as all specimens were tested using vertical loads, even though lateral forces are the most damaging, so clinical implications of the current study must be limited to that application. Also, comparison of stress distribution between various finite element analysis studies is difficult because of different morphology and/or teeth tested, as well as different loadings and vectors used.

\section{CONCLUSION}

1. Thermal fluctuations of temperature have a great influence on the stresses induced on both restoration and tooth structure.

2. IPS e.max CAD produced more favorable stresses on the tooth structure than Vita Enamic.

\section{Acknowledgments}

The authors are grateful to DR. Mohamed EL Anwar for his content contributions and to the participants of the Operative Dentistry Department, Faculty of Oral and Dental Medicine, Al-Azhar University for their support during the development of this manuscript.

\section{Funding}

This research did not receive any specific grant from funding agencies in the public, commercial, or not-for-profit sectors.

\section{Conflict of interest}

The authors have no proprietary, financial, or other personal interest of any nature or kind in any product, service, and/or company that is presented in this article.

\section{Regulatory Statement}

This study was conducted in accordance with all the provisions of the local human subject's oversight committee guidelines and policies of Faculty of Dental Medicine, Al-Azhar University (boys-Cairo).

\section{REFERENCES}

1. Heintze S, Albrecht T, Cavalleri A, Steiner M. A new method to test the fracture probability of all-ceramic crowns with a dual-axis chewing simulator. Dent Mater. 2011;27(2):10-9. doi:10.1016/j.dental.2010.09.004 
2. Kelly J. Clinically relevant approach to failure testing of all-ceramic restorations. J Prosth Dent. 1999;81(6):652-61.doi:10.1016/S00223913(99)70103-4.

3. Zhang Y, Sailer I, Lawn BR. Fatigue of dental ceramics. J Dent. 2013;41(12):1135-47. doi: 10.1016/j.jdent.2013.10.007

4. Jiang $\mathrm{W}, \mathrm{Bo} \mathrm{H}$, Yongchun G, LongXing N. Stress distribution in molars restored with inlays or onlays with or without endodontic treatment:a three-dimensional finite element analysis. J Prosth Dent. 2010;103(1):6-12. doi:10.1016/S0022-3913(09)60206-7

5. Ausiello P, Franciosa P,Martorelli M, Watts D. Numerical fatigue 3D-FE modeling of indirect composite-restored posterior teeth. Dent Mater. 2011;27(5):423-30. doi:10.1016/.jdental.2010.12.001

6. Daneshkazemi A, Jalili Bahabad M, Mirseifinejad R, Amirzade Iranaq M. Stress distribution in four restorative methods in endodontically treated maxillary premolar: A 3D finite element analysis. J Dent Mater an Tech. 2019;8(4):182-9.doi: 10.22038/JDMT.2019.14045

7. Gateau P, Sabek M, Dailey B. In vitro fatigue resistance of glass ionomer cements used in post-and-core applications. J Prosth Dent. 2001;86(2):14955. doi:10.1067/mpr.2001.114882

8. Moeen F, Nisar S, Dar N. A step by step guide to finite element analysis in dental implantology. Pakistan Oral Dent J. 2014;34(1):164-9.

9. Jalalian E, Aletaha N. The effect of two marginal designs (chamfer and shoulder) on the fracture resistance of all ceramic restorations, Inceram: an in vitro study. J Prosthod Res. 2011;55(2):121-5. doi: 10.1016/j.jpor.2010.04.006

10. Hood J. Biomechanics of the intact, prepared and restored tooth: some clinical implications. Int Dent J. 1991;41(1):25-32. PMID:2004835

11. Yang R, Arola D, Han Z, Zhang X. A comparison of the fracture resistance of three machinable ceramics after thermal and mechanical fatigue.J Prosth Dent. 2014;112(4):878-85. doi: 10.1016/j.prosdent.2014.03.005

12. Srirekha A, Bashetty K. Infinite to finite: an overview of finite element analysis. Indian J Dent Res. 2010;21(3):425-32. doi: 10.4103/0970-9290.70813

13. Asmussen E, Peutzfeldt A, Sahafi A. Finite element analysis of stresses in endodontically treated, dowel-restored teeth. J Prosth Dent. 2005;94(4):3219. doi:10.1016/j.prosdent.2005.07.003

14. Nakamura T, Imanishi A, Kashima H, Ohyama T, Ishigaki S. Stress analysis of metal-free polymer crowns using the three-dimensional finite element method. Int JProsthod. 2001;14(5):401-5. PMID: 12066632

15. Scherrer S, De Rijk W, Belser U, Meyer J. Effect of cement film thickness on the fracture resistance of a machinable glass-ceramic. Dent Mater. 1994;10(3):172-7. 10.1016/0109-5641(94)90028-0

16. Anusavice K, Hojjatie B. Influence of incisal length of ceramic and loading orientation on stress distribution in ceramic crowns. J Dent Res. 1988:67(11):1371-5. doi: 10.1177/00220345880670110201

17. Gulec L, Ulusoy N. Effect of endocrown restorations with different CAD/ CAM materials: 3D finite element and weibull analyses. BioMed Res Int. 2017;2017(1):1-10. doi: 10.1155/2017/5638683
18. Yamanel K, Caglar A, Gulsahi K, Ozden U. Effects of different ceramic and composite materials on stress distribution in inlay and onlay cavities:3-D finite element analysis. Dent Mater J. 2009;28(6):661-70. do: 10.4012/ dm. 28.661

19. Yin R, Kim Y, Jang Y, Lee J, Lee M, Bae T. Comparative evaluation of the mechanical properties of CAD/CAM dental blocks. Odontology. 2019;107(3):360-7. doi:10.1007/s10266-018-0407-9

20. Lin C, Chang C, Ko C. Multifactorial analysis of an MOD restored human premolar using auto-mesh finite element approach. J Oral Rehab. 2001;28(6):576-85. doi:10.1046/j.1365-2842.2001.00721.x

21. Ausiello P, Apicella A, Davidson C. Effect of adhesive layer properties on stress distribution in composite restorations a 3D finite element analysis. Dent Mater. 2002;18(4):295-303. doi: 10.1016/s0109-5641(01)00042-2

22. Rees J, Hammadeh M, Jagger D. Abfraction lesion formation in maxillary incisors, canines and premolars: a finite element study. Eur J Oral Sci. 2003;111(2):149-54. doi:10.1034/j.1600-0722.2003.00018.x

23. Federlin M, Krifka S, Herpich M, Hiller K, Schmalz G. Partial ceramic crowns: influence of ceramic thickness, preparation design and luting material on fracture resistance and marginal integrity in vitro. Oper Dent. 2007;32(3):25160. doi: 10.2341/06-70.

24. Dejak B, Mlotkowski A. Three-dimensional finite element analysis of strength and adhesion of composite resin versus ceramic inlays in molars. J Prosth Dent. 2008;99(2):131-40. doi: 10.1016/S0022-3913(08)60029-3

25. Yamanel K, Caglar A, Gulsahi K, Ozden U. Effects of different ceramic and composite materials on stress distribution in inlay and onlay cavities:3-D finite element analysis. Dent Mater J. 2009;28(6):661-70. doi: 10.4012/ dmj.28.661

26. Oskui I, Ashtiani M, Hashemi A, Jafarzadeh H. Effect of thermal stresses on the mechanism of tooth pain. J Endod. 2014;40(11):1835-9. doi: 10.1016/j. joen.2014.06.014

27. Gungor M, Mammadzada S, Sen F, Artunc C. Coupled thermal and structural finite element solution of dental crown structures. Int J Eng Appl Sci. 2010;2(3):11-25.

28. Toparli M, Sasaki S. Finite element analysis of the temperature and thermal stress in a postrestored tooth. J Oral Rehab. 2003;30(9):921-6. doi: 10.1046/.j.1365-2842.2003.01071.x

29. Cornacchia T, Las Casas E, Cimini C, Peixoto R. 3D finite element analysis on esthetic indirect dental restorations under thermal and mechanical loading. Med Biol Eng Computing. 2010;48(11):1107-13. do: 10.1007/s11517-010-0661-7

30. Pałka K, Bienias J, Debski H, Niewczas A. Finite element analysis of thermomechanical loaded teeth. Computational Mater Sci. 2012;64(1):289-94. doi: 10.1007/s11517-010-0661-7

31. Yang $\mathrm{H}, \mathrm{Lang} \mathrm{L}$, Guckes $\mathrm{A}$, Felton $\mathrm{D}$. The effect of thermal change on various dowel-and-core restorative materials. J Prosth Dent. 2001;86(1):74-80. doi: $10.1067 / \mathrm{mpr} .2001 .115503$

\section{Sameh Mahmoud Nabih} (Corresponding address)

Faculty of Dental Medicine, Al-azhar university, Al-Nasr Road, opposite to the International Conference Hall, Nasr City, Cairo, Egypt.

Date submitted: 2020 Aug 20 Accept submission: 2020 Dec 15 